\title{
Change of quality properties of Doenjang according to soaking method in brine
}

\author{
Bo-Young Choi, Na-Young Gil, Shin-Young Park, Yong-Sik Cho, So-Young Kim* \\ Fermented Food Science Division, National Institute of Agricultural Science, Wanju 55365, Korea
}

\section{장 담금법에 따른 된장의 품질 특성 변화}

\author{
최보영 · 길나영 · 박신영 · 조용식 · 김소영* \\ 국립농업과학원 발효식품과
}

\begin{abstract}
This study was carried out to examine the quality characteristics of Doenjang manufactured with or without soaking Meju in brine according to salt concentrations (8 and 12\%) during fermentation for 6 months. The moisture content and salinity of Doenjang fermented for 6 months were 54.9-60.3\% and 7.8-12.5\%, respectively. Doenjang using soaking Meju in brine had higher pH and lower titratable acidity than that using non-soaking Meju. The reducing sugar content in all samples was increased until 2 months and then decreased regardless of soaking Meju, especially that of non-soaking $8 \%$ Doenjang was the highest. The $8 \%$ low-salt Doenjang was shown the highest amino-type nitrogen content, especially the soaking Doenjang was higher than the non-soaking Doenjang. a-amylase activity of all samples during fermentation were continuously decreased from 0.91-0.94 Unit/g to 0.01-0.06 Unit/g, especially the $8 \%$ soaking Doenjang was shown the highest activity after 2 months. Total bacterial count of the soaking Doenjang at the 6 months was in range of 7.8-8.0 log CFU/g and that of the non-soaking Doenjang was in range of 7.2-7.5 $\log \mathrm{CFU} / \mathrm{g}$. By taste analysis, the $8 \%$ soaking Doenjang was shown the similar taste pattem with commercial Doenjang. In conclusion, the $8 \%$ low-salt Doenjang manufactured with soaking Meju in brine was a suitable concentration in order to reduce salt intake.
\end{abstract}

Key words : Doenjang, Low-salt, Meju, Soaking

\section{서 론}

된장은 우리나라 고유의 콩 발효식품으로, 장류는 상고 시대부터 우리 민족의 전통적 식생활의 기본적인 조미료로 상용된 식품이다(1). 된장은 삶은 콩을 메주로 만든 다음 염수에 침지한 후 액을 분리하여 간장을 만들고 고체인 덩어리는 다시 숙성하여 된장을 만든다. 사용하는 전분질 원료에 따라 쌀된장, 보리된장 등이 있고 제조방법이나 부 원료 사용에 따라 막된장, 토장, 막장 및 즙장 등으로 구분하

*Corresponding author. E-mail : foodksy@korea.kr Phone : 82-63-238-3624, Fax : 82-63-238-3843

Received 11 October 2017; Revised 3 November 2017; Accepted 16 November 2017.

Copyright (c) The Korean Society of Food Preservation. All rights reserved.
고 있다. 막된장은 간장을 빼고 난 부산물로 만든 장이고 토장은 막된장과 메주 및 염수를 혼합 숙성했거나, 메주만 으로 담은 된장으로 상온에서 장기 숙성시킨 것이다. 막장 은 토장과 마찬가지로 담되, 수분을 많이 하고 햇볕이나 따뜻한 곳에서 숙성을 촉진시킨 것, 그리고 즙장은 막장과 비슷하게 담되, 수분이 줄줄 흐를 정도로 많고 무나 고추, 배추, 배춧잎을 넣어 숙성시켜 제조한 장을 말한다(2). 그러 나 일반적으로 메주를 만들어 된장을 만드는 전통식과 밀가 루 koji를 만든 후 삶은 콩과 함께 버무려 발효하는 개량식으 로 구분된다(3).

된장의 주원료인 콩은 영양 - 기능적으로 가치가 높은 식재료로 영양학적 측면에서는 단백질과 지방 함량이 높아 필수 아미노산과 필수 지방산의 좋은 급원식품이다(4). 또한 콩에는 플라보노이드로서 isoflavone을 함유하고 있으며 이 들 성분들이 다양한 인체 생리기능에 관여하는 것으로 알려 
져 있어(5), 항암작용(6), 항산화 및 노화억제(7), 혈압강하 (8), 항동맥경화(9), 항혈전용해능(10), 항비만(11), 면역증 진(12) 등과 같은 효과에 관한 다수의 연구를 통해 밝혀져 있다.

최근 전통 한식된장의 제조상 애로사항을 해결하기 위하 여 된장의 제조방법 표준화 및 된장의 영양 기능강화에 관한 많은 연구가 진행되고 있으며, 또한 건강지향 소비자 요구를 반영하여 고염인 장류들의 나트륨 저감화 방안 및 가정에서 쉽게 담가 먹을 수 있는 간편 제조 방법을 제시하 는 연구들이 이루어지고 있다. 겨자, 키토산 등 부재료를 첨가하는 저염 된장(13), 동결건조를 이용해 블록으로 만든 된장(14), 쌀누룩 이용 간편 고추장 제조법(15) 등이 보고되 어 있으나, 가정에서 직접 만들어 먹는 소비가구는 점점 줄어들고 있는 실정이다. 이와 같은 문제를 해소하기 위하 여 시판된장보다 염도를 낮추고, 가정에서 쉽게 제조하여 먹을 수 있도록 제조법을 간편화 등 최근 장류 소비 트렌드 를 반영한 연구가 필요하다.

따라서 본 연구에서는 장 담금 여부에 따른 된장의 이화 학적 특성 변화를 비교 분석하고, 간편 장류 개발을 위한 제조공정 단순화 및 품질 특성에 관한 과학적 근거 자료를 제시하고자 하였다.

\section{재료 및 방법}

재 료

메주는 순창 장류 주식회사에서 대원콩 품종을 사용하여 제조한 약 700-800 g 중량의 된장 제조용 메주를 구입하여 사용하였고, 소금은 신안지역에서 생산된 3년 숙성 천일염 (CJ)을 사용하였다.

\section{된장 제조}

된장 제조를 위해 소금물은 각각 $16,24 \%$ 농도로 만들어 하룻밤 침지시킨 후 용해된 소금물의 불순물 제거를 위해 거름망(mesh size $150 \mu \mathrm{g})$ 으로 걸러 준비하였고, 각각의 스 테인레스 용기에 메주 4개씩을 넣고 소금물을 부은 후 누름 돌로 침수시켜 $30^{\circ} \mathrm{C}$ 항온기에서 3-4주 동안 발효시킨 후 간장과 된장을 분리하여 장 가르기를 한 후, 분리한 된장을 잘게 으깨어 $8,12 \%$ 의 염도로 맞춘 후 $4.5 \mathrm{~L}$ 스테인레스 용기에 담아 $30^{\circ} \mathrm{C}$ 에서 발효시켰으며 메줏가루 된장은 동일 한 메주를 구입하여 분쇄기로 갈아 소금과 물을 배합하여 제조한 후 $30^{\circ} \mathrm{C}$ 에 동일한 조건에서 발효를 진행하였다.

\section{수 분}

수분 함량 측정을 위해 $\mathrm{AOAC}$ 법(16)에 따라 $105^{\circ} \mathrm{C}$ 상압 건조법에 의해 분석하였으며, 된장 $1 \mathrm{~g}$ 을 $105^{\circ} \mathrm{C}$ dry oven (MOV-112, Sanyo Co., Ltd., Osaka, Japan)에서 항량이 될
때까지 건조시켜 백분율(\%)로 계산하였다.

염 도

염도는 $\mathrm{AgNO}_{3}$ 적정법(17)을 변형하여 측정하였다. 된장 $5 \mathrm{~g}$ 에 증류수로 20배 희석하여 진탕배양기(SI-IS20 model, Shin-il Co., Seoul, Korea)에서 $160 \mathrm{rpm}$, 1시간 동안 추출 후 여과지(Advantec No.2)로 여과하고 이 여액 $10 \mathrm{~mL}$ 를 취하고 지시약 $\left(5 \% \mathrm{~K}_{2} \mathrm{CrO}_{4}\right)$ 을 첨가하여 $0.1 \mathrm{~N} \mathrm{AgNO}_{3}$ 로 적정하였다.

$\mathrm{pH}$

된장 시료를 일정량 취하여 증류수로 5 배 희석하고 Homogenizer(Polytron PT-MR 2100, Kinematica AG, Lucerne, Switzerland)로 균질화한 후 $8,000 \mathrm{rpm}$ 에서 10 분간 원심분리(Supra 25k, Hanil Co., Ltd., Incheon, Korea)한 상층 액을 여과지(Advantec No.2)로 여과하여 시료액으로 사용 하였다. 이 시료액을 pH meter(Corning 340, Corning Co., New York, NY, USA)로 분석하였다.

산 도

산도는 $\mathrm{pH}$ 측정에 사용한 동일한 시료액 $10 \mathrm{~mL}$ 에 $1 \%$ phenolphthalein 지시약을 첨가하여 시료의 $\mathrm{pH}$ 가 8.3이 될 때까지 소비된 $0.1 \mathrm{~N} \mathrm{NaOH}$ 의 양을 측정하였다.

\section{환원당}

환원당 함량은 DNS법(18)에 따라 분석하여 측정하였다. 시료액 $1 \mathrm{~mL}$ 에 DNS 시약 $3 \mathrm{~mL}$ 을 혼합하여 $100^{\circ} \mathrm{C}$ 의 물에서 5 분 동안 중탕한 것을 충분히 식힌 후 spectrometer(Libra $\mathrm{S} 35$, Biochrome Ltd., England)를 이용하여 $550 \mathrm{~nm}$ 에서 흡광 도를 측정하였다. 포도당을 표준물질로 하여 작성한 검량 곡선으로부터 환원당 함량(\%)을 계산하였다.

색 도

색도는 색도계(Minolta CR-300, KONICA MINOLTA, Osaka, Japan)를 이용하여 측정한 후 Hunter $\mathrm{L}, \mathrm{a}, \mathrm{b}$ 값과 $\Delta \mathrm{E}$ 값으로 나타내었다.

아미노태 질소

아미노태 질소 $\left(\mathrm{NO}_{3}-\mathrm{N}\right)$ 는 Formol법(16)을 토대로 일부 변형하여 측정하였다. 시료액 $5 \mathrm{~mL}$ 에 중성 formalin $(\mathrm{pH} 8.3)$ $10 \mathrm{~mL}$ 과 증류수 $10 \mathrm{~mL}$ 을 넣어 $0.1 \mathrm{~N} \mathrm{NaOH}$ 로 $\mathrm{pH} 8.4$ 가 될 때까지 중화하기 위해 적정하였다. 이때 소모된 $0.1 \mathrm{~N}$ $\mathrm{NaOH} \mathrm{mL}$ 수를 아미노태 질소함량으로 결정하였다. 대조 구는 중성 formalin을 대신하여 증류수를 사용하여 측정하 였다.

암모니아태 질소

암모니아태 질소 $\left(\mathrm{NH}_{4}-\mathrm{N}\right)$ 는 시료액 $0.1 \mathrm{~mL}$ 에 $\mathrm{A}$ 용액과 
$\mathrm{B}$ 용액을 각각 $2 \mathrm{~mL}$ 씩 차례로 넣고 $37^{\circ} \mathrm{C}$ 에서 20 분간 반응시 켜 spectrometer(Libra S35, Biochrome Ltd., England)를 이용 하여 $630 \mathrm{~nm}$ 에서 흡광도를 측정하였다. 황산암모늄 $\left(\left(\mathrm{NH}_{4}\right)_{2} \mathrm{SO}_{4}\right)$ 을 표준물질로 하여 작성한 검량곡선으로부터 암모니아태 질소 함량 $(\mathrm{mg} \%)$ 을 계산하였다(A용액: phenol $10 \mathrm{~g}$ and sodium nitroprusside dehydrate $0.05 \mathrm{~g}$ in distilled water 1,000 mL; B용액: $\mathrm{Na}_{2} \mathrm{HPO}_{4} \cdot 12 \mathrm{H}_{2} \mathrm{O} 9 \mathrm{~g}, \mathrm{NaOH} 6 \mathrm{~g}$ and $\mathrm{NaOCl} 10 \mathrm{~mL}$ in distilled water $1,000 \mathrm{~mL}$ ).

\section{효소 활성}

$\mathrm{a}$-amylase 활성 측정을 위해 된장 시료 $2 \mathrm{~g}$ 에 증류수로 10배 희석하고 진탕배양기(Shin-il, Korea)에서 $180 \mathrm{rpm}, 4$ 시간동안 추출한 후 하룻밤 냉장보관 후 여과지(Advantec No.2)로 여과하여 조효소액을 제조하였다. 그리고 나서 $1 \%$ 전분 기질용액 $1 \mathrm{~mL}$ 을 $40^{\circ} \mathrm{C}$ 에서 5 분간 예열시킨 후 조효소 액 $50 \mu \mathrm{L}$ 를 첨가하여 반응액을 제조하였다. 즉시 이 반응액 $50 \mu \mathrm{L}$ 에 요오드 용액 $5 \mathrm{~mL}$ 을 넣어 대조구로 하였으며 $30^{\circ} \mathrm{C}$ incubation에서 30 분간 반응시킨 반응액 $50 \mu \mathrm{L}$ 에 요오드 용액 $5 \mathrm{~mL}$ 을 첨가한 실험구를 각각 $660 \mathrm{~nm}$ 에서 흡광도를 측정하여 a-amylase 효소활성을 측정하였다(19).

Protease 효소 활성 측정은 Anson의 방법을 일부 변형하 여 수행하였다(20). $0.6 \%$ casein 기질용액 $100 \mu \mathrm{L}$ 와 준비된 조효소액 $100 \mu \mathrm{L}$ 를 각각 취하여 $37^{\circ} \mathrm{C}$ 에서 10 분간 방치하였 다. 그 후 반응을 정지시키기 위해 $0.4 \mathrm{M}$ trichloroacetic $\operatorname{acid}(\mathrm{TCA})$ 용액 $200 \mu \mathrm{L}$ 를 넣고 $37^{\circ} \mathrm{C}$ 에서 25 분간 반응시켰 다. 이 용액의 침전물을 제거하기 위해 원심분리하여 상층 액 $100 \mu \mathrm{L}$ 를 취하고, 여기에 $0.4 \mathrm{M}$ 탄산나트륨 $500 \mu \mathrm{L}$ 와 3 배 희석한 Folin 시약 $100 \mu \mathrm{L}$ 를 넣어 $37^{\circ} \mathrm{C}$ 에서 20 분간 반응시킨 후 $660 \mathrm{~nm}$ 에서 흡광도를 측정하였다. 효소의 1 unit는 1 umole의 tyrosine을 유리시키는 효소의 양으로 하였 다.

\section{미생물 수}

된장 $1 \mathrm{~g}$ 에 $0.85 \%(\mathrm{w} / \mathrm{v})$ 생리식염수 $9 \mathrm{~mL}$ 을 시험관에 담아 균질화시키고 이를 십진희석법으로 희석하여 총균수 는 plate count agar(Difco Lab. Detroit, MI, USA), 유산균수 는 MRS(Difco Lab.)배지를 이용하여 접종 도말하였다. 총 균수는 $37^{\circ} \mathrm{C}$ 에서 24 시간동안 호기배양을, 유산균수는 48-72시간동안 혐기배양한 후 형성된 집락을 2 회 반복 계수 하여 $\log \mathrm{CFU} / \mathrm{g}$ 로 환산하여 표시하였다.

\section{맛 센서 이용한 관능검사(taste sensing analysis)}

발효기간에 따른 된장의 맛 변화를 살펴보기 위하여 맛 센서 분석기(TS-5000Z, Insent, Atsugi, Japan)를 이용하여 수행하였다. 된장 시료의 전처리는 각각의 시료 $2 \mathrm{~g}$ 을 취해 증류수로 5 배 희석한 후 원심 분리하여 얻은 상등액을 여과 하여 시료로 사용하였다. 맛 센서 분석기에 시료를 $70 \mathrm{~mL}$ 씩
넣어 3회 반복 측정한 후, 평균값을 구하여 쓴맛(bitter), 짠맛(saltiness), 신맛(sourness), 감칠맛(umami), 떫은맛 (astringency)의 값을 객관적으로 나타내었다(21).

\section{유리아미노산 함량 측정}

유리아미노산은 아미노산 자동 분석기(L-8900, Hitachi Co., Ltd., Tokyo, Japan)를 사용하였다. 시료 $2 \mathrm{~g}$ 에 물 18 $\mathrm{mL}$ 를 가한 다음 $100^{\circ} \mathrm{C}$ 에서 10 분간 가열 한 후 원심분리( $4^{\circ} \mathrm{C}, 5,000 \times \mathrm{g}, 10 \mathrm{~min}$ ) 하였다. 상층액 $1 \mathrm{~mL}$ 를 취하고 여기 에 $5 \%$ 트리클로로초산(trichloroacetic acid, Junsei Chemical Co., Ltd., Tokyo, Japan) $1 \mathrm{~mL}$ 를 첨가한 후 재차 원심분리 $\left(4^{\circ} \mathrm{C}, 12,000 \times \mathrm{g}, 15 \mathrm{~min}\right)$ 하였다. 상층액을 회수하고 0.02 $\mathrm{N} \mathrm{HCl}(\mathrm{pH}$ 2.2)으로 2배 희석하고 여과 $(0.2 \mu \mathrm{m}$, Millipore Co., Cork, Ireland)한 것을 분석하였다. 분석에는 PF\#2622 (4.6×60 mm, Hitachi Co., Ltd.) 컬럼(column)을 사용하였으 며 칼럼 오븐의 온도는 $57^{\circ} \mathrm{C}$, 반응기의 온도는 $136^{\circ} \mathrm{C}$ 로 설정 하였고 발색에는 닌히드린(ninhydrin, Wako Pure Chemical Industrial, Ltd., Osaka, Japan) 용액을 사용하였다.

\section{통계처리}

미생물 수를 제외한 모든 실험은 3회 반복 실험하여 평균 과 표준편차로 나타내었고, 실험값에 대한 통계분석은 SAS 9.2 program(SAS Institute Inc., Cary, NC, USA)을 이용하여 통계처리 하였으며, Duncan's multiple range test 방법과 $\mathrm{t}$-test를 이용하여 평균값 간에 유의수준 $\mathrm{p}<0.05$ 에서 유의성 을 검정하였다.

\section{결과 및 고찰}

\section{수분 및 염도}

염 농도 $(8,12 \%)$ 와 염수 침지 여부를 고려한 장 담금법을 달리하여 제조한 4 종의 된장을 6 개월 동안 발효하면서 품 질특성을 살펴보았고, Table 1에 수분 함량 및 염도의 변화 를 조사하여 나타내었다.

수분 함량에서는 장 담금 전에 $24 \%$ 염수에 메주를 침지 하여 제조한 $12 \%$ 메주된장이 $55.5 \pm 0.5 \%$ 로 가장 낮은 수분 함량을 보였으며, 발효가 완료된 6 개월 후에도 $54.9 \pm 0.4 \%$ 로 여전히 그 값을 유지하였다. 반면 나머지 3종 $(8 \%$ 메주, $8,12 \%$ 메줏가루 된장)은 담금 초기 60.5-61.3\%로 높았지 만, 발효가 진행되면서 약간 감소하여 평균 $60 \%$ 를 유지하 였다. 우리나라 전통식품규격기준(22)에 따르면 전통된장 의 수분함량이 $60 \%$ 이하로 규정되어 있어 본 실험에서 제조 한 $8 \%$ 메주 된장과 메줏가루로 제조한 된장의 경우 수분 함량이 높았기에 장 가르기를 할 때 충분한 탈수과정과 메줏가루 된장 제조 시에 수분 첨가 비율을 낮추는 방법 
Table 1. Change on moisture and salinity of Doenjang according to manufacturing method of soybean paste during fermentation period

\begin{tabular}{|c|c|c|c|c|c|c|c|c|c|c|}
\hline \multirow{2}{*}{ Contents } & \multirow{2}{*}{$\begin{array}{l}\text { Doenjang } \\
\text { group }\end{array}$} & \multirow{2}{*}{$\begin{array}{l}\mathrm{NaCl} \\
(\%)\end{array}$} & \multicolumn{8}{|c|}{ Fermentation period (week) } \\
\hline & & & 0 & 2 & 4 & 8 & 12 & 16 & 20 & 24 \\
\hline \multirow{4}{*}{$\begin{array}{c}\text { Moisture } \\
(\%)\end{array}$} & \multirow{2}{*}{$\begin{array}{c}\text { Soaking } \\
\text { Doenjang }\end{array}$} & 8 & $61.3 \pm 0.4^{\text {al }}$ & $60.5 \pm 0.4^{b}$ & $61.7 \pm 0.7^{\mathrm{a}}$ & $60.7 \pm 0.1^{b}$ & $60.0 \pm 0.6^{b}$ & $59.7 \pm 0.5^{b}$ & $59.2 \pm 0.1^{b}$ & $60.3 \pm 0.4^{\mathrm{ab}}$ \\
\hline & & 12 & $55.5 \pm 0.5^{\mathrm{b}}$ & $55.6 \pm 0.3^{\mathrm{c}}$ & $56.0 \pm 0.1^{\mathrm{b}}$ & $56.1 \pm 0.7^{\mathrm{c}}$ & $55.5 \pm 0.3^{\mathrm{c}}$ & $54.7 \pm 0.3^{\mathrm{c}}$ & $54.2 \pm 0.5^{\mathrm{c}}$ & $54.9 \pm 0.4^{\mathrm{c}}$ \\
\hline & \multirow{2}{*}{$\begin{array}{c}\text { Non-soaking } \\
\text { Doenjang }\end{array}$} & 8 & $60.5 \pm 0.4^{\mathrm{a}}$ & $61.7 \pm 0.2^{\mathrm{a}}$ & $61.9 \pm 0.6^{\mathrm{a}}$ & $62.4 \pm 0.5^{\mathrm{a}}$ & $61.2 \pm 0.1^{\mathrm{a}}$ & $60.5 \pm 0.5^{\mathrm{a}}$ & $60.3 \pm 0.6^{\mathrm{a}}$ & $60.2 \pm 0.2^{\mathrm{a}}$ \\
\hline & & 12 & $61.2 \pm 0.8^{\mathrm{a}}$ & $61.7 \pm 0.2^{\mathrm{a}}$ & $61.4 \pm 1.0^{\mathrm{a}}$ & $61.8 \pm 0.8^{\mathrm{ab}}$ & $60.1 \pm 0.2^{\mathrm{b}}$ & $59.2 \pm 0.1^{\mathrm{b}}$ & $59.5 \pm 0.5^{\mathrm{ab}}$ & $60.1 \pm 0.8^{\mathrm{b}}$ \\
\hline \multirow{4}{*}{$\begin{array}{c}\text { Salinity } \\
(\%)\end{array}$} & \multirow{2}{*}{$\begin{array}{c}\text { Soaking } \\
\text { Doenjang }\end{array}$} & 8 & $8.1 \pm 0.1^{c}$ & $8.3 \pm 0.1^{c}$ & $8.0 \pm 0.1^{c}$ & $7.9 \pm 0.0^{c}$ & $8.2 \pm 0.0^{c}$ & $8.3 \pm 0.1^{\mathrm{d}}$ & $8.1 \pm 0.1^{\mathrm{c}}$ & $7.9 \pm 0.1^{\mathrm{c}}$ \\
\hline & & 12 & $12.7 \pm 0.2^{\mathrm{a}}$ & $13.0 \pm 0.3^{\mathrm{a}}$ & $13.0 \pm 0.0^{\mathrm{a}}$ & $13.0 \pm 0.1^{\mathrm{a}}$ & $13.0 \pm 0.3^{\mathrm{a}}$ & $12.6 \pm 0.1^{\mathrm{a}}$ & $12.7 \pm 0.2^{\mathrm{a}}$ & $12.5 \pm 0.1^{\mathrm{a}}$ \\
\hline & \multirow{2}{*}{$\begin{array}{c}\text { Non-soaking } \\
\text { Doenjang }\end{array}$} & 8 & $8.2 \pm 0.1^{\mathrm{c}}$ & $8.3 \pm 0.1^{\mathrm{c}}$ & $8.1 \pm 0.1^{\mathrm{c}}$ & $8.0 \pm 0.0^{\mathrm{c}}$ & $8.3 \pm 0.0^{\mathrm{c}}$ & $8.5 \pm 0.1^{\mathrm{c}}$ & $8.1 \pm 0.0^{\mathrm{c}}$ & $7.8 \pm 0.0^{\mathrm{c}}$ \\
\hline & & 12 & $12.2 \pm 0.1^{\mathrm{b}}$ & $12.1 \pm 0.4^{b}$ & $12.0 \pm 0.1^{\mathrm{b}}$ & $12.2 \pm 0.3^{\mathrm{b}}$ & $11.9 \pm 0.1^{\mathrm{b}}$ & $12.1 \pm 0.1^{\mathrm{b}}$ & $11.6 \pm 0.1^{b}$ & $11.9 \pm 0.4^{b}$ \\
\hline
\end{tabular}

${ }^{1)}$ Means \pm SD ( $\left.n=3\right)$ within each column followed by the same letter are not significantly different $(\mathrm{p}<0.05)$.

등을 고려하여 조절해야할 것으로 사료된다.

된장의 염도 변화는 식염 농도 $8,12 \%$ 로 구분하여 보았을 때 담금 초기의 염도 값이 각각 8.1-8.2와 12.2-12.7\%이었고, 발효 후 7.8-7.9와 11.9-12.5\%로 약간 감소하는 경향을 나타 내었다. 그러나 각 시료별로 발효기간 동안 염도 변화를 살펴보았을 때 그다지 큰 차이를 보이지 않아 발효기간 및 장 담금법에 따른 염도변화는 보이지 않는 것으로 판단 된다.

\section{$\mathrm{pH}$, 산도 및 환원당}

장담금법에 따른 된장의 $\mathrm{pH}$, 산도 및 환원당 변화는 Table 2 에 제시하였다. 담금 초기 $\mathrm{pH}$ 값은 $8 \%$ 메주 된장의 경우 $5.7 \pm 0.0,12 \%$ 메주 된장에서 $5.3 \pm 0.0$ 으로 메줏가루된

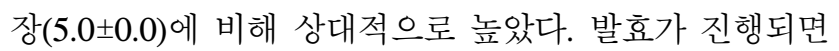

서 대부분 $\mathrm{pH}$ 값이 조금 낮아졌는데 특히, 발효 4주 차 이후 부터 $8 \%$ 메주 된장은 5.2-5.4를 유지하며 가장 높은 값을 나타내었고, 염수 침지 과정을 거치지 않은 메줏가루 된장 은 4.9-5.0 범위로 낮은 값을 유지하였다. 6개월의 발효기간 동안 $8 \%$ 메주 된장에서는 초기보다 $\mathrm{pH}$ 값이 소폭 낮아졌으 나, 이외의 시료들에 비해 상대적으로 담금 초기부터 발효 가 완료될 때까지 높은 값을 나타내었다.

산도 변화는 담금 직후에는 메주 된장에서 메줏가루 된 장보다 낮은 값을 보였는데, 메주 된장은 $1.3 \%$ 로 낮은 값을, 메줏가루 된장은 1.9-2.0\%로 높은 값을 나타내었다. 발효가 진행되면서 점차 산도 값이 높아지다가 발효 2-3개월째부 터 감소하는 경향을 보였는데, 발효 완료 시에는 메줏가루 된장(2.1-2.3\%)에 비해 메주 된장(1.8-1.9\%)이 조금 더 낮은 값을 유지하였다.

Table 2. Change on pH, titratable acidity and reducing sugar of Doenjang according to manufacturing method of soybean paste during fermentation period

\begin{tabular}{|c|c|c|c|c|c|c|c|c|c|c|}
\hline \multirow{2}{*}{ Contents } & \multirow{2}{*}{$\begin{array}{l}\text { Doenjang } \\
\text { group }\end{array}$} & \multirow{2}{*}{$\begin{array}{c}\mathrm{NaCl} \\
(\%)\end{array}$} & \multicolumn{8}{|c|}{ Fermentation period (week) } \\
\hline & & & 0 & 2 & 4 & 8 & 12 & 16 & 20 & 24 \\
\hline \multirow{4}{*}{$\mathrm{pH}$} & \multirow{2}{*}{$\begin{array}{l}\text { Soaking } \\
\text { Doenjang }\end{array}$} & 8 & $5.7 \pm 0.0^{\mathrm{a} 1)}$ & $5.6 \pm 0.0^{\mathrm{a}}$ & $5.2 \pm 0.0^{\mathrm{a}}$ & $5.3 \pm 0.0^{\mathrm{a}}$ & $5.3 \pm 0.0^{\mathrm{a}}$ & $5.3 \pm 0.0^{\mathrm{a}}$ & $5.4 \pm 0.0^{\mathrm{a}}$ & $5.3 \pm 0.0^{\mathrm{a}}$ \\
\hline & & 12 & $5.3 \pm 0.0^{\mathrm{b}}$ & $5.3 \pm 0.0^{\mathrm{b}}$ & $5.2 \pm 0.0^{\mathrm{b}}$ & $5.1 \pm 0.0^{\mathrm{b}}$ & $5.1 \pm 0.0^{\mathrm{b}}$ & $5.1 \pm 0.0^{\mathrm{b}}$ & $5.1 \pm 0.0^{\mathrm{b}}$ & $5.0 \pm 0.0^{\mathrm{b}}$ \\
\hline & \multirow{2}{*}{$\begin{array}{l}\text { Non-soaking } \\
\text { Doenjang }\end{array}$} & 8 & $5.0 \pm 0.0^{c}$ & $5.0 \pm 0.0^{c}$ & $5.0 \pm 0.0^{c}$ & $4.9 \pm 0.0^{\mathrm{d}}$ & $4.9 \pm 0.1^{\mathrm{c}}$ & $4.9 \pm 0.0^{\mathrm{c}}$ & $5.1 \pm 0.0^{\mathrm{b}}$ & $5.0 \pm 0.0^{\mathrm{b}}$ \\
\hline & & 12 & $5.0 \pm 0.0^{\mathrm{c}}$ & $5.0 \pm 0.0^{\mathrm{c}}$ & $5.0 \pm 0.0^{\mathrm{c}}$ & $5.0 \pm 0.0^{\mathrm{c}}$ & $4.9 \pm 0.0^{\mathrm{c}}$ & $4.9 \pm 0.0^{\mathrm{c}}$ & $5.0 \pm 0.0^{\mathrm{b}}$ & $4.9 \pm 0.0^{\mathrm{c}}$ \\
\hline \multirow{4}{*}{$\begin{array}{l}\text { Titratable acidity } \\
(\%)\end{array}$} & \multirow{2}{*}{$\begin{array}{l}\text { Soaking } \\
\text { Doenjang }\end{array}$} & 8 & $1.3 \pm 0.0^{\mathrm{d}}$ & $1.6 \pm 0.0^{\mathrm{d}}$ & $2.1 \pm 0.0^{\mathrm{b}}$ & $2.2 \pm 0.0^{\mathrm{b}}$ & $1.9 \pm 0.0^{\mathrm{b}}$ & $2.1 \pm 0.0^{\mathrm{b}}$ & $2.2 \pm 0.0^{\mathrm{b}}$ & $1.8 \pm 0.0^{\mathrm{d}}$ \\
\hline & & 12 & $1.3 \pm 0.0^{c}$ & $1.6 \pm 0.0^{c}$ & $1.9 \pm 0.0^{c}$ & $2.0 \pm 0.0^{c}$ & $1.8 \pm 0.0^{c}$ & $2.0 \pm 0.1^{\mathrm{b}}$ & $1.9 \pm 0.0^{\mathrm{d}}$ & $1.9 \pm 0.0^{c}$ \\
\hline & \multirow{2}{*}{$\begin{array}{l}\text { Non-soaking } \\
\text { Doenjang }\end{array}$} & 8 & $2.0 \pm 0.0^{\mathrm{a}}$ & $2.2 \pm 0.0^{\mathrm{a}}$ & $2.2 \pm 0.0^{\mathrm{a}}$ & $2.3 \pm 0.0^{\mathrm{a}}$ & $2.3 \pm 0.1^{\mathrm{a}}$ & $2.4 \pm 0.0^{\mathrm{a}}$ & $2.3 \pm 0.1^{\mathrm{a}}$ & $2.3 \pm 0.0^{\mathrm{a}}$ \\
\hline & & 12 & $1.9 \pm 0.0^{\mathrm{b}}$ & $2.0 \pm 0.0^{\mathrm{b}}$ & $2.0 \pm 0.0^{\mathrm{b}}$ & $2.2 \pm 0.0^{\mathrm{b}}$ & $2.0 \pm 0.0^{\mathrm{b}}$ & $2.1 \pm 0.0^{\mathrm{b}}$ & $2.0 \pm 0.0^{\mathrm{c}}$ & $2.1 \pm 0.0^{\mathrm{b}}$ \\
\hline \multirow{4}{*}{$\begin{array}{l}\text { Reducing sugar } \\
(\%)\end{array}$} & \multirow{2}{*}{$\begin{array}{l}\text { Soaking } \\
\text { Doenjang }\end{array}$} & 8 & $2.0 \pm 0.1^{\mathrm{b}}$ & $2.2 \pm 0.0^{d}$ & $2.1 \pm 0.0^{d}$ & $2.3 \pm 0.2^{d}$ & $1.9 \pm 0.0^{\mathrm{d}}$ & $0.9 \pm 0.0^{d}$ & $0.9 \pm 0.0^{d}$ & $1.3 \pm 0.0^{\mathrm{d}}$ \\
\hline & & 12 & $1.9 \pm 0.1^{\mathrm{bc}}$ & $2.4 \pm 0.0^{\mathrm{c}}$ & $2.5 \pm 0.1^{\mathrm{c}}$ & $2.5 \pm 0.0^{\mathrm{c}}$ & $2.2 \pm 0.0^{\mathrm{c}}$ & $1.0 \pm 0.0^{\mathrm{c}}$ & $1.0 \pm 0.0^{\mathrm{c}}$ & $1.5 \pm 0.0^{\mathrm{c}}$ \\
\hline & \multirow{2}{*}{$\begin{array}{l}\text { Non-soaking } \\
\text { Doenjang }\end{array}$} & 8 & $2.4 \pm 0.1^{\mathrm{a}}$ & $3.3 \pm 0.1^{\mathrm{a}}$ & $3.3 \pm 0.1^{\mathrm{a}}$ & $3.6 \pm 0.1^{\mathrm{a}}$ & $3.0 \pm 0.0^{\mathrm{a}}$ & $1.5 \pm 0.1^{\mathrm{a}}$ & $1.5 \pm 0.0^{\mathrm{a}}$ & $2.3 \pm 0.0^{\mathrm{a}}$ \\
\hline & & 12 & $1.8 \pm 0.1^{\mathrm{c}}$ & $2.8 \pm 0.1^{\mathrm{b}}$ & $2.9 \pm 0.2^{\mathrm{b}}$ & $2.9 \pm 0.0^{\mathrm{b}}$ & $2.7 \pm 0.0^{\mathrm{b}}$ & $1.3 \pm 0.0^{\mathrm{b}}$ & $1.2 \pm 0.0^{\mathrm{b}}$ & $1.9 \pm 0.0^{\mathrm{b}}$ \\
\hline
\end{tabular}

${ }^{1)}$ Means \pm SD ( $\mathrm{n}=3$ ) within each column followed by the same letter are not significantly different $(\mathrm{p}<0.05)$. 
환원당 함량은 $1-2$ 개월 내에 최대값을 나타내고 이후 감소하였으며, 염 농도 $8 \%$ 메줏가루 된장이 발효기간 동안 $1.5 \pm 0.1-3.6 \pm 0.1 \%$ 로 가장 높았으며, 염 농도는 같으나 장 담금법이 다른 $8 \%$ 메주 된장이 0.9 $\pm 0.0-2.3 \pm 0.2 \%$ 로 가장 낮은 값을 나타냈다. 이는 장 담금 후에는 미생물에 의해 생성된 amylase의 높은 활성에 의해 탄수화물이 분해되어 환원당 함량이 높았지만, 발효기간이 진행될수록 미생물영 양원 또는 유기산 발효의 기질로 유리당이 소모되어 환원당 함량이 감소된 것으로 사료된다(23). 또한 메줏가루 된장의 환원당이 높은 이유는 장 가르기 과정을 거치는 메주 된장
에 비해 메줏가루 된장은 염수 침지 과정이 생략되어 고형 분 함량이 상대적으로 높고, 이로 인해 발효미생물 생육도 활발하여 분비된 가수분해효소 활성이 높아 환원당 함량도 높은 것으로 추측된다.

\section{색 도}

발효에 따른 된장의 색도 변화를 관찰하여 Table 3에 제시하였다. 명도(lightness, L) 값은 메주 된장 $(45.8 \pm 0.5$ -46.9 \pm 0.4$)$ 보다 메줏가루 된장(54.4 $\pm 0.4-55.6 \pm 0.3)$ 의 값이 높아 밝은 색을 띠었다가 점차 어두워져 6개월 발효기간

Table 3. Change on color of Doenjang according to manufacturing method of soybean paste during fermentation period

\begin{tabular}{|c|c|c|c|c|c|c|c|c|c|c|}
\hline \multirow{2}{*}{ Items } & \multirow{2}{*}{$\begin{array}{l}\text { Doenjang } \\
\text { group }\end{array}$} & \multirow{2}{*}{$\begin{array}{l}\mathrm{NaCl} \\
(\%)\end{array}$} & \multicolumn{8}{|c|}{ Fermentation period (week) } \\
\hline & & & 0 & 2 & 4 & 8 & 12 & 16 & 20 & 24 \\
\hline \multirow{4}{*}{$\mathrm{L}$} & \multirow{2}{*}{$\begin{array}{l}\text { Soaking } \\
\text { Doenjang }\end{array}$} & 8 & $46.9 \pm 0.4^{\mathrm{cl})}$ & $45.0 \pm 0.8^{\mathrm{c}}$ & $44.0 \pm 0.2^{\mathrm{b}}$ & $40.5 \pm 0.4^{\mathrm{b}}$ & $38.4 \pm 0.2^{\mathrm{b}}$ & $38.5 \pm 0.2^{\mathrm{b}}$ & $38.3 \pm 0.7^{\mathrm{a}}$ & $35.7 \pm 0.1^{\mathrm{b}}$ \\
\hline & & 12 & $45.8 \pm 0.5^{\mathrm{d}}$ & $46.0 \pm 0.4^{b}$ & $43.8 \pm 0.2^{\mathrm{b}}$ & $42.8 \pm 1.0^{\mathrm{a}}$ & $40.8 \pm 0.6^{\mathrm{a}}$ & $40.4 \pm 0.1^{\mathrm{a}}$ & $37.9 \pm 0.9^{\mathrm{ab}}$ & $37.6 \pm 0.1^{\mathrm{a}}$ \\
\hline & \multirow{2}{*}{$\begin{array}{l}\text { Non-soaking } \\
\text { Doenjang }\end{array}$} & 8 & $55.6 \pm 0.3^{\mathrm{a}}$ & $49.0 \pm 0.1^{\mathrm{a}}$ & $45.0 \pm 0.2^{\mathrm{a}}$ & $40.5 \pm 0.7^{b}$ & $37.9 \pm 0.2^{\mathrm{b}}$ & $36.2 \pm 0.0^{\mathrm{c}}$ & $34.2 \pm 0.1^{\mathrm{c}}$ & $34.1 \pm 0.2^{\mathrm{d}}$ \\
\hline & & 12 & $54.4 \pm 0.4^{\mathrm{b}}$ & $48.7 \pm 0.5^{\mathrm{a}}$ & $45.4 \pm 0.8^{\mathrm{a}}$ & $41.4 \pm 0.2^{b}$ & $38.7 \pm 0.7^{\mathrm{b}}$ & $38.5 \pm 0.2^{b}$ & $37.1 \pm 0.8^{\mathrm{b}}$ & $35.4 \pm 0.2^{\mathrm{c}}$ \\
\hline \multirow{4}{*}{$\mathrm{a}$} & \multirow{2}{*}{$\begin{array}{l}\text { Soaking } \\
\text { Doenjang }\end{array}$} & 8 & $5.9 \pm 0.1^{\mathrm{d}}$ & $6.8 \pm 0.2^{\mathrm{b}}$ & $7.6 \pm 0.3^{\mathrm{c}}$ & $8.6 \pm 0.2^{b}$ & $7.7 \pm 0.2^{\mathrm{c}}$ & $8.4 \pm 0.1^{\mathrm{c}}$ & $7.4 \pm 0.1^{b}$ & $7.6 \pm 0.3^{d}$ \\
\hline & & 12 & $6.3 \pm 0.1^{\mathrm{c}}$ & $7.0 \pm 0.3^{\mathrm{b}}$ & $8.1 \pm 0.3^{\mathrm{b}}$ & $9.1 \pm 0.3^{\mathrm{b}}$ & $7.6 \pm 0.1^{\mathrm{c}}$ & $8.5 \pm 0.1^{\mathrm{c}}$ & $6.5 \pm 1.1^{\mathrm{b}}$ & $8.1 \pm 0.1^{\mathrm{c}}$ \\
\hline & \multirow{2}{*}{$\begin{array}{l}\text { Non-soaking } \\
\text { Doenjang }\end{array}$} & 8 & $7.3 \pm 0.1^{\mathrm{a}}$ & $8.7 \pm 0.2^{\mathrm{a}}$ & $10.1 \pm 0.1^{\mathrm{a}}$ & $11.0 \pm 0.4^{\mathrm{a}}$ & $8.9 \pm 0.1^{\mathrm{b}}$ & $9.6 \pm 0.0^{\mathrm{b}}$ & $8.9 \pm 0.2^{\mathrm{a}}$ & $9.3 \pm 0.1^{\mathrm{b}}$ \\
\hline & & 12 & $6.8 \pm 0.2^{\mathrm{b}}$ & $8.4 \pm 0.1^{\mathrm{a}}$ & $10.1 \pm 0.1^{\mathrm{a}}$ & $11.3 \pm 0.2^{\mathrm{a}}$ & $9.4 \pm 0.4^{\mathrm{a}}$ & $11.7 \pm 0.1^{\mathrm{a}}$ & $9.7 \pm 0.1^{\mathrm{a}}$ & $9.7 \pm 0.1^{\mathrm{a}}$ \\
\hline \multirow{4}{*}{$\mathrm{b}$} & \multirow{2}{*}{$\begin{array}{l}\text { Soaking } \\
\text { Doenjang }\end{array}$} & 8 & $15.5 \pm 0.0^{b}$ & $14.8 \pm 0.5^{\mathrm{c}}$ & $14.7 \pm 0.3^{\mathrm{c}}$ & $13.4 \pm 0.2^{\mathrm{c}}$ & $11.2 \pm 0.3^{b}$ & $11.2 \pm 0.1^{b}$ & $9.5 \pm 0.5^{\mathrm{b}}$ & $8.9 \pm 0.6^{\mathrm{c}}$ \\
\hline & & 12 & $15.8 \pm 0.2^{\mathrm{b}}$ & $15.9 \pm 0.4^{\mathrm{b}}$ & $15.8 \pm 0.6^{\mathrm{b}}$ & $15.2 \pm 0.5^{\mathrm{b}}$ & $11.3 \pm 0.0^{\mathrm{b}}$ & $10.7 \pm 0.0^{\mathrm{c}}$ & $11.5 \pm 0.4^{\mathrm{a}}$ & $10.8 \pm 0.0^{\mathrm{a}}$ \\
\hline & \multirow{2}{*}{$\begin{array}{l}\text { Non-soaking } \\
\text { Doenjang }\end{array}$} & 8 & $19.9 \pm 0.6^{\mathrm{a}}$ & $20.0 \pm 0.3^{\mathrm{a}}$ & $18.8 \pm 0.5^{\mathrm{a}}$ & $15.0 \pm 0.2^{\mathrm{b}}$ & $11.4 \pm 0.1^{\mathrm{b}}$ & $9.9 \pm 0.1^{\mathrm{d}}$ & $8.5 \pm 0.3^{\mathrm{c}}$ & $8.1 \pm 0.0^{\mathrm{d}}$ \\
\hline & & 12 & $20.4 \pm 0.2^{\mathrm{a}}$ & $19.6 \pm 0.6^{\mathrm{a}}$ & $18.6 \pm 0.4^{\mathrm{a}}$ & $16.7 \pm 0.3^{\mathrm{a}}$ & $12.7 \pm 0.2^{\mathrm{a}}$ & $13.8 \pm 0.2^{\mathrm{a}}$ & $11.3 \pm 0.4^{\mathrm{a}}$ & $10.1 \pm 0.2^{b}$ \\
\hline \multirow{4}{*}{$\triangle \mathrm{E}$} & \multirow{2}{*}{$\begin{array}{l}\text { Soaking } \\
\text { Doenjang }\end{array}$} & 8 & $55.3 \pm 0.4^{\mathrm{b}}$ & $57.0 \pm 0.8^{\mathrm{a}}$ & $58.0 \pm 0.3^{\mathrm{a}}$ & $61.2 \pm 0.4^{\mathrm{a}}$ & $62.7 \pm 0.2^{\mathrm{a}}$ & $62.6 \pm 0.2^{\mathrm{c}}$ & $62.5 \pm 0.6^{b}$ & $64.9 \pm 0.2^{\mathrm{c}}$ \\
\hline & & 12 & $56.4 \pm 0.5^{\mathrm{a}}$ & $56.3 \pm 0.6^{\mathrm{a}}$ & $58.5 \pm 0.0^{\mathrm{a}}$ & $59.5 \pm 1.1^{\mathrm{b}}$ & $60.3 \pm 0.6^{b}$ & $60.7 \pm 0.1^{d}$ & $57.8 \pm 3.8^{\mathrm{c}}$ & $63.3 \pm 0.1^{\mathrm{d}}$ \\
\hline & \multirow{2}{*}{$\begin{array}{l}\text { Non-soaking } \\
\text { Doenjang }\end{array}$} & 8 & $48.8 \pm 0.5^{d}$ & $55.1 \pm 0.2^{\mathrm{b}}$ & $58.6 \pm 0.1^{\mathrm{a}}$ & $62.0 \pm 0.7^{\mathrm{a}}$ & $63.4 \pm 0.2^{\mathrm{a}}$ & $64.9 \pm 0.0^{\mathrm{a}}$ & $66.6 \pm 0.1^{\mathrm{a}}$ & $66.6 \pm 0.2^{\mathrm{a}}$ \\
\hline & & 12 & $50.1 \pm 0.4^{\mathrm{c}}$ & $55.2 \pm 0.4^{b}$ & $58.2 \pm 0.7^{\mathrm{a}}$ & $61.6 \pm 0.2^{\mathrm{a}}$ & $62.8 \pm 0.7^{\mathrm{a}}$ & $63.7 \pm 0.3^{\mathrm{b}}$ & $64.3 \pm 0.7^{\mathrm{ab}}$ & $65.7 \pm 0.2^{\mathrm{b}}$ \\
\hline
\end{tabular}

${ }^{1)}$ Means \pm SD ( $\mathrm{n}=3$ ) within each column followed by the same letter are not significantly different $(\mathrm{p}<0.05)$.

\begin{tabular}{|c|c|c|c|c|}
\hline & $A^{1)}$ & B & $\mathrm{C}$ & $\mathrm{D}$ \\
\hline 0 Week & & & & \\
\hline 12 Weeks & & & & \\
\hline 24 Weeks & & & & \\
\hline
\end{tabular}

\footnotetext{
${ }^{1]} \mathrm{A}, 8 \% \mathrm{NaCl}$ soaking Doenjang; B, $8 \% \mathrm{NaCl}$ non-soaking Doenjang; C, 12\% NaCl soaking Doenjang; D, $12 \% \mathrm{NaCl}$ non-soaking Doenjang.
} 
후에는 담금법에 따른 시료 간의 차이가 없어 비슷한 밝기 를 보였다(34.1 $\pm 0.2-37.6 \pm 0.1)$. 또한 적색도(redness, a) 값은 발효기간 동안 메줏가루 된장이 높은 값을 보였으며, 꾸준 히 증가하다가 2 개월 이후로 감소하는 경향을 보였다. 황색 도(yellowness, b)에서도 메줏가루 된장의 값이 높았으나, 발효기간 동안 모든 시료의 값이 꾸준히 감소되는 값을 나타내었다.

이와 같이 된장은 발효가 진행되면서 갈변 현상을 보이 며 색 변화가 나타나는데, 이 값을 변색도 $(\Delta \mathrm{E})$ 로 나타내었 을 때 모든 시료들은 발효기간이 길어질수록 점진적으로 변화하였고, 특히 메줏가루 된장에서 더 큰 색변화를 보였 다. 이와 같은 현상은 Chang 등(24)이 보고한 바와 같이 콩의 단백질과 전분이 분해되어 생성된 당과 아미노산의 화학반응인 mallard 반응에 의한 갈색화로 인한 것으로, 발효식품인 된장은 장 담금 방법에 따라 이런 현상이 다르 게 나타날 수 있음을 알 수 있었다.
아미노태 및 암모니아태 질소

장 담금법을 달리하여 제조한 된장을 6 개월 동안 발효시 키면서 아미노태 질소 및 암모니아태 질소 함량 변화를 살펴보고 Table 4에 그 결과를 나타내었다. 아미노태 질소 함량변화는 담금 직후에는 염 농도가 낮을 수록 높은 값을 나타냈으며, 메주 된장에서 메줏가루 된장보다 높은 값을 보였다. $8 \%$ 메주 된장은 $773.7 \pm 9.1 \mathrm{mg} \%, 12 \%$ 메주 된장은 $614.6 \pm 2.8 \mathrm{mg} \%$ 로 염 농도에 따른 함량 차이를 보였으며 8 과 $12 \%$ 염농도의 메줏가루 된장은 각각 $444.7 \pm 2.1$ 과 $355.6 \pm 14.0 \mathrm{mg} \%$ 으로 메주 된장과 값 차이가 컸으며 메주 된장과 마찬가지로 $8 \%$ 로 염 농도가 낮은 시료에서 아미노 태 질소 함량이 더 높게 나타났다. 이는 Lee 등(25)의 보고에 서 낮은 염 농도에서 16 주 동안 발효시킨 된장이 protease 등 단백질 분해에 관여하는 효소 활성이 높아 아미노태 질소 함량이 높았다고 본 연구와 유사한 결과를 보여주었 다.

암모니아태 질소 함량은 발효초기부터 $8 \%$ 메주 된장이

Table 4. Changes in amino- and ammonia-type nitrogen contents of Doenjang according to manufacturing method of soybean paste during fermentation period

\begin{tabular}{|c|c|c|c|c|c|c|c|c|c|c|}
\hline & \multirow{2}{*}{$\begin{array}{l}\text { Doenjang } \\
\text { group }\end{array}$} & \multirow{2}{*}{$\begin{array}{l}\mathrm{NaCl} \\
(\%) \\
\end{array}$} & \multicolumn{8}{|c|}{ Fermentation period (week) } \\
\hline & & & 0 & 2 & 4 & 8 & 12 & 16 & 20 & 24 \\
\hline \multirow{4}{*}{$\begin{array}{c}\text { Amino-type } \\
\text { nitrogen } \\
\text { (mg\%) }\end{array}$} & \multirow{2}{*}{$\begin{array}{l}\text { Soaking } \\
\text { Doenjang }\end{array}$} & 8 & $773.7 \pm 9.1^{\text {al) }}$ & $1,066.3 \pm 5.7^{\mathrm{a}}$ & $1,241.3 \pm 2.1^{\mathrm{a}}$ & $1,358.5 \pm 11.2^{\mathrm{a}}$ & $1,379.0 \pm 3.5^{\mathrm{a}}$ & $1,444.5 \pm 5.0^{\mathrm{a}}$ & $1,484.8 \pm 16.9^{\mathrm{a}}$ & $1,462.4 \pm 9.7^{\mathrm{a}}$ \\
\hline & & 12 & $614.6 \pm 2.8^{\mathrm{b}}$ & $841.4 \pm 7.0^{c}$ & $1,004.7 \pm 7.7^{\mathrm{c}}$ & $1,071.5 \pm 16.8^{\mathrm{c}}$ & $1,094.8 \pm 12.6^{\mathrm{c}}$ & $1,172.7 \pm 26.1^{\mathrm{c}}$ & $1,179.1 \pm 19.5^{\mathrm{c}}$ & $1,143.8 \pm 26.2^{\mathrm{c}}$ \\
\hline & \multirow{2}{*}{$\begin{array}{l}\text { Non-soaking } \\
\text { Doenjang }\end{array}$} & 8 & $444.7 \pm 2.1^{\mathrm{c}}$ & $944.1 \pm 6.3^{b}$ & $1,160.1 \pm 4.9^{\mathrm{b}}$ & $1,239.5 \pm 15.4^{b}$ & $1,215.2 \pm 18.9^{b}$ & $1,344.5 \pm 12.1^{b}$ & $1,366.7 \pm 41.9^{\mathrm{b}}$ & $1,325.0 \pm 22.4^{\mathrm{b}}$ \\
\hline & & 12 & $355.6 \pm 14.0^{\mathrm{d}}$ & $794.3 \pm 2.1^{\mathrm{d}}$ & $900.2 \pm 4.2^{\mathrm{d}}$ & $985.6 \pm 10.5^{\mathrm{d}}$ & $1,092.5 \pm 23.8^{\mathrm{c}}$ & $1,166.2 \pm 9.2^{\mathrm{c}}$ & $1,179.0 \pm 12.4^{\mathrm{c}}$ & $1,158.9 \pm 7.9^{\mathrm{c}}$ \\
\hline \multirow{4}{*}{$\begin{array}{l}\text { Ammonia-type } \\
\text { nitrogen } \\
(\mathrm{mg} \%)\end{array}$} & \multirow{2}{*}{$\begin{array}{l}\text { Soaking } \\
\text { Doenjang }\end{array}$} & 8 & $12.7 \pm 0.9^{\mathrm{d}}$ & $3.4 \pm 0.2^{c}$ & $2.8 \pm 0.2^{\mathrm{c}}$ & $2.5 \pm 0.2^{\mathrm{b}}$ & $0.9 \pm 0.1^{\mathrm{b}}$ & $0.6 \pm 0.2^{\mathrm{b}}$ & $1.5 \pm 0.1^{\mathrm{b}}$ & $1.1 \pm 0.0^{\mathrm{b}}$ \\
\hline & & 12 & $18.4 \pm 0.1^{\mathrm{c}}$ & $7.5 \pm 0.2^{\mathrm{a}}$ & $4.4 \pm 0.2^{\mathrm{a}}$ & $1.7 \pm 0.2^{\mathrm{c}}$ & $1.3 \pm 0.1^{\mathrm{a}}$ & $1.0 \pm 0.2^{\mathrm{a}}$ & $2.3 \pm 0.3^{\mathrm{a}}$ & $1.8 \pm 0.2^{\mathrm{a}}$ \\
\hline & \multirow{2}{*}{$\begin{array}{l}\text { Non-soaking } \\
\text { Doenjang }\end{array}$} & 8 & $24.4 \pm 0.5^{b}$ & $4.6 \pm 0.2^{b}$ & $3.2 \pm 0.2^{b}$ & $2.0 \pm 0.2^{\mathrm{c}}$ & $0.7 \pm 0.1^{\mathrm{b}}$ & $0.5 \pm 0.0^{\mathrm{b}}$ & $1.0 \pm 0.2^{\mathrm{c}}$ & $1.0 \pm 0.0^{\mathrm{b}}$ \\
\hline & & 12 & $47.5 \pm 0.4^{\mathrm{a}}$ & $7.5 \pm 0.2^{\mathrm{a}}$ & $4.6 \pm 0.2^{\mathrm{a}}$ & $3.1 \pm 0.2^{\mathrm{a}}$ & $1.0 \pm 0.3^{\mathrm{b}}$ & $0.7 \pm 0.0^{\mathrm{b}}$ & $1.8 \pm 0.1^{\mathrm{b}}$ & $1.7 \pm 0.1^{\mathrm{a}}$ \\
\hline
\end{tabular}

${ }^{1)}$ Means \pm SD ( $\left.n=3\right)$ within each column followed by the same letter are not significantly different $(\mathrm{p}<0.05)$.
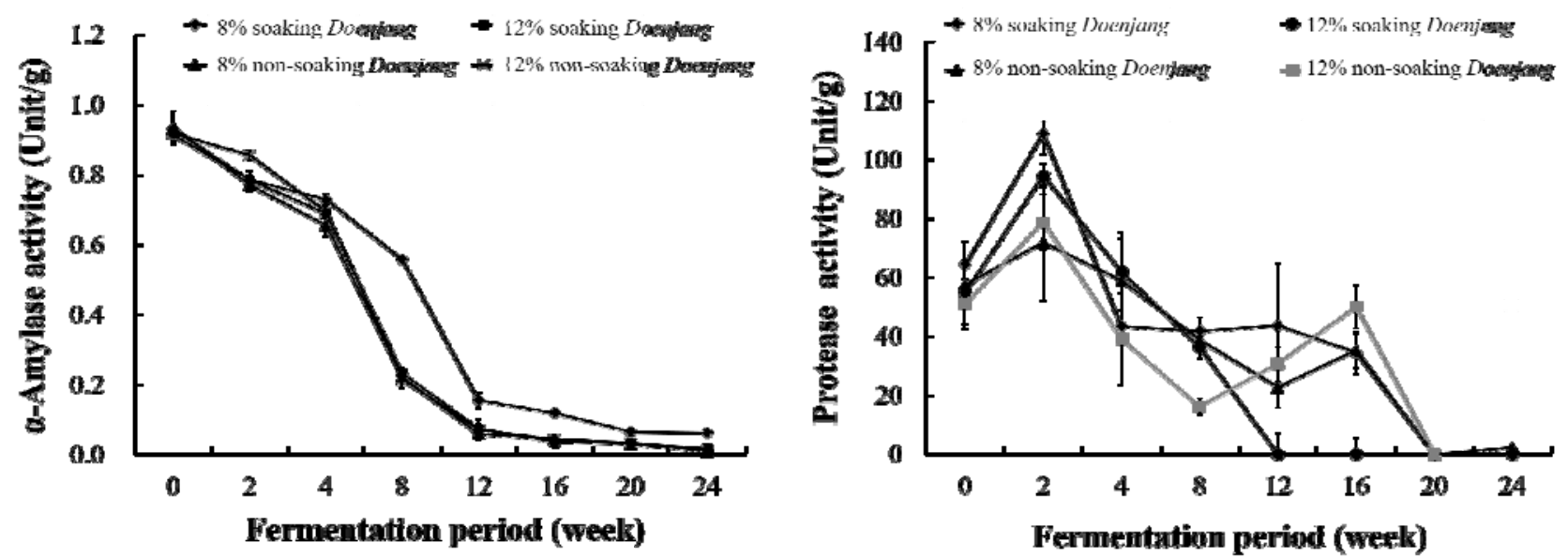

Fig. 1. Changes on enzymatic activity of a-amylase and protease of Doenjang according to manufacturing method of soybean paste during fermentation period. 
$12.7 \pm 0.9 \mathrm{mg} \%$ 로 가장 낮은 값을 보였고, 발효 6개월 후에도 $8 \%$ 메줏가루 된장과 함께 $1.0 \pm 0.0 \mathrm{mg} \%$ 로 가장 낮은 값을 나타내었다. $12 \%$ 메줏가루 된장은 $47.5 \pm 0.4 \mathrm{mg} \%$ 로 가장 높은 값을 나타냈으며 동일한 염 농도의 메주 된장보다 높은 값을 보였다. 그러나 이후 급격히 감소하여 2주차에는 $7.5 \pm 0.2 \mathrm{mg} \%$ 로 낮은 값을 나타내다, 꾸준히 감소하여 발효 6개월째 $1.7 \pm 0.1 \mathrm{mg} \%$ 로 $12 \%$ 메주 된장과 비슷한 수준으로 낮은 값을 보였다. Lee 등(25)이 염 농도가 낮을수록 휘발성 염기질소 중 하나인 암모니아태 질소 함량이 높은 값을 나타내고, 발효가 진행되면서 지속적으로 증가하였다고 보 고한 내용과는 상이하였다.
점차 감소하여, 발효기간은 다르지만 Mok 등(26)의 protease 효소 활성이 증가하였다가 감소하는 경향을 나타 냈다는 보고와 유사하였다.

\section{미생물 변화}

된장은 발효하는 동안 미생물 생육으로 인해 생성된 효 소작용으로 맛과 향을 비롯하여 품질에 영향을 받는다. 이 에 염도와 온도를 달리하여 제조한 된장을 장기간 발효시키 면서 미생물 생육 변화를 살펴보았다(Table 5).

총 균수는 발효초기 메주 된장(7.6-7.9 $\log \mathrm{CFU} / \mathrm{g}$ )에서 메줏가루 된장(6.5-6.9 $\log \mathrm{CFU} / \mathrm{g})$ 보다 높은 값을 나타냈다.

Table 5. Aerobic bacteria and lactic acid bacteria cell numbers of Doenjang according to manufacturing method of soybean paste during fermentation period

\begin{tabular}{|c|c|c|c|c|c|c|c|c|c|c|}
\hline \multirow{2}{*}{ Bacterial group } & \multirow{2}{*}{$\begin{array}{l}\text { Doenjang } \\
\text { group }\end{array}$} & \multirow{2}{*}{$\begin{array}{l}\mathrm{NaCl} \\
(\%)\end{array}$} & \multicolumn{8}{|c|}{ Bacterial cell count (log CFU/g) during fermentation (week) } \\
\hline & & & 0 & 2 & 4 & 8 & 12 & 16 & 20 & 24 \\
\hline \multirow{4}{*}{ Aerobic bacteria } & \multirow{2}{*}{$\begin{array}{l}\text { Soaking } \\
\text { Doenjang }\end{array}$} & 8 & $7.6 \pm 0.0^{\mathrm{al})}$ & $7.7 \pm 0.1^{\mathrm{a}}$ & $7.3 \pm 0.4^{\mathrm{a}}$ & $7.9 \pm 0.1^{\mathrm{a}}$ & $8.0 \pm 0.1^{\mathrm{a}}$ & $8.0 \pm 0.1^{\mathrm{a}}$ & $8.4 \pm 0.1^{\mathrm{a}}$ & $8.0 \pm 0.1^{\mathrm{a}}$ \\
\hline & & 12 & $7.9 \pm 0.1^{\mathrm{a}}$ & $7.5 \pm 0.2^{\mathrm{ab}}$ & $7.3 \pm 0.0^{\mathrm{a}}$ & $7.8 \pm 0.0^{\mathrm{a}}$ & $7.9 \pm 0.1^{\mathrm{a}}$ & $7.9 \pm 0.1^{\mathrm{a}}$ & $7.8 \pm 0.1^{\mathrm{b}}$ & $7.8 \pm 0.1^{b}$ \\
\hline & \multirow{2}{*}{$\begin{array}{l}\text { Non-soaking } \\
\text { Doenjang }\end{array}$} & 8 & $6.9 \pm 0.1^{\mathrm{b}}$ & $7.1 \pm 0.1^{\mathrm{b}}$ & $7.3 \pm 0.0^{\mathrm{a}}$ & $7.4 \pm 0.1^{\mathrm{b}}$ & $7.5 \pm 0.0^{\mathrm{b}}$ & $7.6 \pm 0.1^{\mathrm{a}}$ & $7.3 \pm 0.1^{\mathrm{c}}$ & $7.2 \pm 0.0^{\mathrm{d}}$ \\
\hline & & 12 & $6.5 \pm 0.2^{\mathrm{c}}$ & $7.5 \pm 0.2^{\mathrm{ab}}$ & $7.1 \pm 0.1^{\mathrm{a}}$ & $7.4 \pm 0.1^{\mathrm{b}}$ & $7.4 \pm 0.1^{\mathrm{b}}$ & $7.2 \pm 0.2^{\mathrm{b}}$ & $7.4 \pm 0.0^{\mathrm{c}}$ & $7.5 \pm 0.0^{\mathrm{c}}$ \\
\hline \multirow{4}{*}{$\begin{array}{l}\text { Lactic acid } \\
\text { bacteria }\end{array}$} & \multirow{2}{*}{$\begin{array}{l}\text { Soaking } \\
\text { Doenjang }\end{array}$} & 8 & $5.1 \pm 0.0^{\mathrm{a}}$ & $3.6 \pm 0.0^{\mathrm{b}}$ & $0.0 \pm 0.0^{\mathrm{b}}$ & $0.0 \pm 0.0^{\mathrm{a}}$ & $0.0 \pm 0.0^{\mathrm{a}}$ & $0.0 \pm 0.0^{\mathrm{a}}$ & $0.0 \pm 0.0^{\mathrm{a}}$ & $0.0 \pm 0.0^{\mathrm{a}}$ \\
\hline & & 12 & $4.8 \pm 0.0^{\mathrm{b}}$ & $0.0 \pm 0.0^{\mathrm{d}}$ & $0.0 \pm 0.0^{\mathrm{b}}$ & $0.0 \pm 0.0^{\mathrm{a}}$ & $0.0 \pm 0.0^{\mathrm{a}}$ & $0.0 \pm 0.0^{\mathrm{a}}$ & $0.0 \pm 0.0^{\mathrm{a}}$ & $0.0 \pm 0.0^{\mathrm{a}}$ \\
\hline & \multirow{2}{*}{$\begin{array}{l}\text { Non-soaking } \\
\text { Doenjang }\end{array}$} & 8 & $4.1 \pm 0.0^{c}$ & $4.3 \pm 0.0^{\mathrm{a}}$ & $1.7 \pm 0.0^{\mathrm{ab}}$ & $0.0 \pm 0.0^{\mathrm{a}}$ & $0.0 \pm 0.0^{\mathrm{a}}$ & $0.0 \pm 0.0^{\mathrm{a}}$ & $0.0 \pm 0.0^{\mathrm{a}}$ & $0.0 \pm 0.0^{\mathrm{a}}$ \\
\hline & & 12 & $5.3 \pm 0.0^{\mathrm{a}}$ & $2.6 \pm 0.0^{\mathrm{c}}$ & $3.7 \pm 0.0^{\mathrm{a}}$ & $0.0 \pm 0.0^{\mathrm{a}}$ & $0.0 \pm 0.0^{\mathrm{a}}$ & $0.0 \pm 0.0^{\mathrm{a}}$ & $0.0 \pm 0.0^{\mathrm{a}}$ & $0.0 \pm 0.0^{\mathrm{a}}$ \\
\hline
\end{tabular}

${ }^{1)}$ Means \pm SD ( $\mathrm{n}=3$ ) within each column followed by the same letter are not significantly different $(\mathrm{p}<0.05)$.

\section{효소 활성}

된장은 주원료인 콩에서 발효과정을 거치면서 단백질과 전분질이 가수분해 되면서 유리된 성분들에 의해 된장의 단맛과 구수한 맛이 결정되는데 이 과정에서 미생물에 의해 분비된 amylase와 protease 등의 효소가 깊이 관련된다. 이 에 6개월 간 발효시키면서 된장 내 효소 활성 변화를 측정하 여 Fig. 1에 나타내었다.

먼저 a-amylase 효소 활성 변화를 살펴 본 결과, 발효 초기에는 0.91-0.94 Unit/g 수준으로 비슷한 값을 나타내어 시료 간에 차이를 보이지 않았다. 이후 꾸준히 감소하여 모든 시료는 발효 6개월째 0.01-0.06 Unit/g 값을 나타내었 다. 이들 중 $8 \%$ 메주 된장은 다른 시료들에 비해 발효 4개월 동안 완만한 감소를 보였지만, Mok 등(26)의 보고에서 저염 된장이 16 주의 숙성기간 동안 a-amylase 효소 활성이 초기 와 비슷한 수준을 유지하였다는 결과와는 상이하였다.

Protease 효소 활성은 장 담금 초기에는 메주 된장이 메줏 가루 된장에 비해 활성이 높았는데 발효 2주차에 $8 \%$ 와 $12 \%$ 메주된장이 $108.9 \pm 7.6$ 와 $94.7 \pm 3.9 \mathrm{Unit} / \mathrm{g}$ 로 월등히 높 은 값을, 메줏가루 된장이 $71.8 \pm 19.4$ 와 79.0 $\pm 9.4 \mathrm{Unit} / \mathrm{g}$ 로 낮은 값을 나타내었다. 그러나 이후 protease 효소 활성은
발효기간 동안에 모든 시료에서 총 균수가 늘어났는데 발효 6개월째는 메주 된장에서 7.8-8.0 $\log \mathrm{CFU} / \mathrm{g}$, 메줏가루 된장 에서 7.2-7.5 $\log \mathrm{CFU} / \mathrm{g}$ 로 발효 초기와 같이 메주 된장에서 통계적으로 유의하게 높은 값을 보였다. 염 농도에 따라서 는 메주 된장에서는 8 와 $12 \%$ 메주 된장이 발효초기부터 발효 4 개월까지는 비슷한 수준이었으나, 발효 5 개월 후부 터 $8 \%$ 메주 된장이 조금 더 높은 값을 보였다. 그러나 메줏 가루 된장의 경우 발효 전후에 염 농도에 따른 차이 없이 비슷한 수준의 총 균수값을 보였다.

유산균은 증식하면서 생산한 유기산과 박테리오신과 같 은 물질에 의해 오염균 증식을 방지하는 반면 과잉 생산된 젓산에 의한 산도 증가로 된장에 강한 신맛을 부여하여 기호도에 영향을 준다. Table 5에 나타낸 바와 같이 유산균 수는 담금 초기에는 일정한 수준으로 검출되었으나, 2개월 이후 모든 된장시료들에서 유산균이 검출되지 않았다. 이 는 비록 42 일의 짭은 발효기간 동안이지만 발효초기에 비 해 발효가 진행되면서 꾸준히 유산균수가 감소하였다는 Lee 등(27)의 보고와 유사한 경향을 나타내었다. 


\section{맛 센서를 이용한 맛 성분 분석}

장 담금법을 달리하여 제조한 된장의 발효에 따른 맛의 변화를 살펴보기 위하여 염도 $12 \%$ 의 시중 판매 된장을 대조군으로 비교 분석하여 그 결과를 Fig. 2에 나타내었다. 맛 센서를 이용한 분석 결과로는 대조군으로 사용한 시판된 장이 제조한 된장보다 깊은 맛(richness)은 높고 짠맛 (saltness)과 후미(aftertaste B)는 낮아 가장 관능적 특성이 높았다. 장 담금 유무에 따른 시료들 간에 비교에서는 6개월 간 발효시킨 $8 \%$ 메주 된장이 깊은 맛(richness)과 감칠 맛 (umami)을 비롯하여 대조군 시료와 가장 유사한 맛 패턴을 보였다. 그러나 염도 및 장 담금법에 따른 시료된장들 간에 명확한 차이를 보이지 않아 보다 정밀한 맛 평가를 위해서 전문 패널을 이용한 관능검사를 병행해야 할 것으로 판단된 다.

\section{유리아미노산 함량}

된장의 숙성 전, 후 유리아미노산의 함량은 Table 6와 같다. 숙성 전 된장의 유리아미노산 총량은 $8 \%$ 메주 된장 $1,384.42$, 메줏가루 된장 $725.09 \mu \mathrm{g} / \mathrm{mL}, 12 \%$ 메주 된장
$1,088.25$, 메줏가루 된장 $654.04 \mu \mathrm{g} / \mathrm{mL}$ 이었으나 숙성 후에 는 각각 $2,544.19,2,248.29,1,888.92,1,985.31 \mu \mathrm{g} / \mathrm{mL}$ 으로 증가하였다. 숙성기간 동안 메주 된장은 $8 \%$ 에서 1.8 배, $12 \%$ 에서는 1.7 배 증가한 반면 메줏가루 된장에서는 각각 3.1배, 3 배 증가하여, 메줏가루 된장의 증가폭이 컸다. 강한 감칠맛이 있고 우리나라 전통된장에 가장 많이 함유(28)되 어 있는 glutamic acid는 $8 \%$ 메주 된장 336.63 , 메줏가루 된장 $279.73 \mu \mathrm{g} / \mathrm{mL}, 12 \%$ 메주 된장 222.59 , 메줏가루 된장 $247.46 \mu \mathrm{g} / \mathrm{mL}$ 으로 숙성 전 함량 68.97-181.05 $\mu \mathrm{g} / \mathrm{ml}$ 에 비하 여 1.7-3.6배 증가하였다. 숙성기간 동안 가장 크게 증가한 성분은 valine, isoleucine, lysine, leucine, glutamic acid, threonine, serine, phenylalanine 이며 미세한 쓴맛을 가지고 있는 leucine, isoleucine, valine (29)은 숙성기간 동안 각각 1.9-4.7, 2.2-6.9, 2.5-5.4배 증가하였으며, 강한 단맛을 가지 고 있는 alanine(29)의 함량은 숙성에 의해서 1.9-4.0배 증가 하였다. 소량성분에 있어서 장가르기 여부에 따른 유리 아 미노산 함량은 약한 쓴맛을 가지고 있는 tyrosine은 메주 된장에서는 1.7-2.0, 메줏가루 된장에서는 2.7-29배 증가하 였으며, $\gamma$-aminobutyric acid(GABA)는 고혈압 및 심혈관
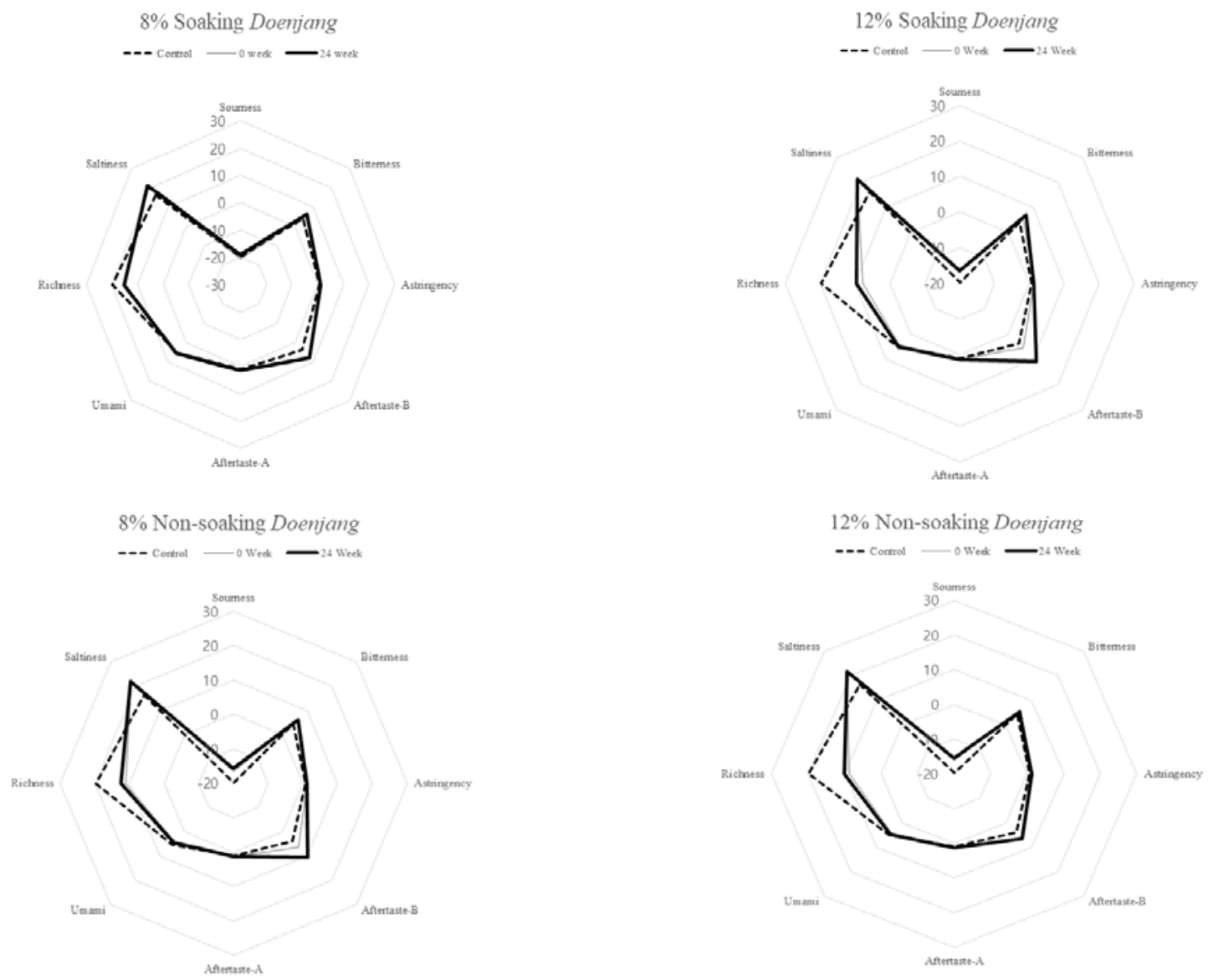

Fig. 2. Taste intensities of the fermented Doenjang.

-.-- (dotted line) Control, - (light full line) before fermentation for 0 week, - (bold full line) after fermentation for 24 weeks. 
Table 6. Free amino acid contents in Doenjang according to manufacturing method of soybean paste during fermentation period

$(\mathrm{mg} / \mathrm{L})$

\begin{tabular}{|c|c|c|c|c|c|c|c|c|c|}
\hline \multirow{3}{*}{ Compounds } & $\mathrm{NaCl}(\%)$ & \multicolumn{4}{|c|}{8} & \multicolumn{4}{|c|}{12} \\
\hline & \multirow{2}{*}{$\begin{array}{c}\begin{array}{c}\text { Fermentation } \\
\text { period (week) }\end{array} \\
\begin{array}{c}\text { Doenjang } \\
\text { group }\end{array}\end{array}$} & \multicolumn{2}{|c|}{0} & \multicolumn{2}{|c|}{24} & \multicolumn{2}{|c|}{0} & \multicolumn{2}{|c|}{24} \\
\hline & & $\begin{array}{c}\text { Soaking } \\
\text { Doenjang }\end{array}$ & $\begin{array}{l}\text { Non-soaking } \\
\text { Doenjang }\end{array}$ & $\begin{array}{c}\text { Soaking } \\
\text { Doenjang }\end{array}$ & $\begin{array}{l}\text { Non-soaking } \\
\text { Doenjang }\end{array}$ & $\begin{array}{l}\text { Soaking } \\
\text { Doenjang }\end{array}$ & $\begin{array}{c}\text { Non-soaking } \\
\text { Doenjang }\end{array}$ & $\begin{array}{c}\text { Soaking } \\
\text { Doenjang }\end{array}$ & $\begin{array}{c}\text { Non-soaking } \\
\text { Doenjang }\end{array}$ \\
\hline \multicolumn{2}{|c|}{ Alanine } & 62.01 & 29.74 & 47.61 & 24.50 & 126.80 & 113.03 & 89.37 & 97.81 \\
\hline \multicolumn{2}{|c|}{ Ammonia } & $\mathrm{ND}^{1)}$ & ND & ND & ND & ND & ND & ND & ND \\
\hline \multicolumn{2}{|c|}{ Anserine } & ND & ND & $\mathrm{ND}$ & $\mathrm{ND}$ & ND & ND & ND & $\mathrm{ND}$ \\
\hline \multicolumn{2}{|c|}{ Arginine } & 13.56 & 31.24 & 25.72 & 25.70 & 0.29 & 0.79 & 1.08 & 0.67 \\
\hline \multicolumn{2}{|c|}{ Aspartic acid } & 63.60 & 21.92 & 46.65 & 20.21 & 193.92 & 153.25 & 114.75 & 125.98 \\
\hline \multicolumn{2}{|c|}{ a-Aminoadioic acid } & 9.42 & 13.84 & 9.95 & 12.00 & 3.49 & 6.00 & 6.62 & 7.70 \\
\hline \multicolumn{2}{|c|}{ a-Aminobutyric acid } & 1.95 & 2.38 & 1.06 & 2.16 & 0.47 & 0.59 & 0.17 & 0.43 \\
\hline \multicolumn{2}{|c|}{ ß-Alanine } & 5.38 & 8.13 & 5.97 & 7.24 & 12.79 & 16.29 & 11.33 & 13.08 \\
\hline \multicolumn{2}{|c|}{$\gamma$-Aminobutyric acid } & 5.99 & 8.53 & 6.75 & 7.58 & 4.16 & 7.20 & 4.77 & 6.22 \\
\hline \multicolumn{2}{|c|}{$\beta$-Aminoisobutyric acid } & 14.09 & 16.15 & 13.77 & 13.24 & 5.86 & 10.44 & 9.26 & 9.40 \\
\hline \multicolumn{2}{|c|}{ Carnosine } & 3.94 & 0.83 & 0.88 & 12.38 & 8.86 & ND & 5.91 & $\mathrm{ND}$ \\
\hline \multicolumn{2}{|c|}{ Citrulline } & 64.69 & 12.66 & 41.74 & 11.47 & 48.23 & 60.96 & 74.92 & 70.46 \\
\hline \multicolumn{2}{|c|}{ Cystathionine } & ND & 0.58 & $\mathrm{ND}$ & 0.52 & 0.46 & 0.26 & $\mathrm{ND}$ & $\mathrm{ND}$ \\
\hline \multicolumn{2}{|c|}{ Cysteine } & ND & ND & $\mathrm{ND}$ & ND & ND & ND & ND & $\mathrm{ND}$ \\
\hline \multicolumn{2}{|c|}{ Ethanolamine } & 278.83 & 187.64 & 248.29 & 188.68 & 485.08 & 420.25 & 374.78 & 389.35 \\
\hline \multicolumn{2}{|c|}{ Glutamic acid } & 181.05 & 82.11 & 127.26 & 68.97 & 336.63 & 279.73 & 222.59 & 247.46 \\
\hline & & 41.24 & 11.73 & 28.65 & 10.00 & 108.58 & 89.96 & 60.64 & 68.38 \\
\hline & & 30.01 & 11.79 & 22.39 & 11.94 & 54.06 & 48.55 & 38.58 & 41.87 \\
\hline Hydrc & lysine & ND & ND & ND & ND & ND & ND & ND & $\mathrm{ND}$ \\
\hline Hydro & roline & ND & ND & ND & ND & ND & ND & ND & $\mathrm{ND}$ \\
\hline & & 59.38 & 17.36 & 43.04 & 14.42 & 133.86 & 113.64 & 95.53 & 99.83 \\
\hline & & 97.44 & 43.02 & 75.35 & 33.32 & 202.57 & 180.44 & 146.62 & 156.04 \\
\hline & & 95.16 & 61.84 & 80.76 & 53.34 & 153.83 & 153.57 & 124.70 & 139.36 \\
\hline Met & & 16.63 & 7.56 & 12.83 & 5.81 & 32.94 & 27.84 & 22.90 & 24.61 \\
\hline 3-Meth & istidine & ND & 1.98 & ND & 3.97 & ND & 1.05 & ND & 1.18 \\
\hline & & 29.64 & 25.07 & 25.76 & 21.93 & 42.25 & 58.44 & 38.94 & 42.31 \\
\hline Pheny & anine & 69.32 & 32.18 & 53.49 & 26.36 & 123.75 & 109.69 & 92.53 & 95.75 \\
\hline Phosphoe & nolamine & ND & ND & $\mathrm{ND}$ & ND & ND & ND & ND & $\mathrm{ND}$ \\
\hline Phosp & serine & ND & ND & $\mathrm{ND}$ & $\mathrm{ND}$ & ND & $\mathrm{ND}$ & ND & $\mathrm{ND}$ \\
\hline & & ND & ND & ND & ND & ND & ND & ND & ND \\
\hline & & ND & 5.13 & 1.96 & 3.22 & ND & ND & 0.92 & 1.17 \\
\hline & & 62.66 & 17.80 & 43.25 & 14.18 & 139.99 & 128.93 & 102.77 & 111.30 \\
\hline & & ND & ND & ND & ND & ND & ND & ND & ND \\
\hline & & 44.39 & 12.91 & 32.93 & 10.54 & 103.74 & 92.97 & 75.04 & 80.70 \\
\hline Tryl & & ND & ND & $\mathrm{ND}$ & ND & ND & ND & ND & $\mathrm{ND}$ \\
\hline & & 33.34 & 16.70 & 12.95 & 12.45 & ND & ND & ND & ND \\
\hline & & 53.42 & 21.63 & 38.98 & 19.58 & 139.30 & 116.05 & 95.70 & 100.73 \\
\hline & & $1,384.42$ & 725.09 & $1,088.25$ & 654.04 & $2,544.19$ & $2,248.29$ & $1,888.92$ & $1,985.31$ \\
\hline
\end{tabular}

${ }^{1} \mathrm{ND}$, not detected. 
조절 기능이 있는 것으로 잘 알려져 있는 성분으로(30) 메주 된장에서는 $70 \%$, 메줏가루 된장에서는 $80 \%$ 로 감소하였으 나, $\mathrm{GABA}$ 와 구조가 유사하며 중추신경계에서 신경전달물 질로 작용하는 $\beta$-alanine(31)은 메주 된장에서는 1.9-2.4, 메 줏가루 된장에서는 1.8-2.0배 증가하는 것으로 나타났다. 즉, 유리 아미노산 함량은 숙성 기간 동안 장가르기 여부에 따라 메줏가루에서 증가폭은 컸으나, 메주 된장의 절대값 이 높았으며, 염도별로는 숙성 후 $8 \%$ 된장이 $12 \%$ 된장보다 유리 아미노산 함량이 높았다.

\section{요 약}

염수 침지 여부를 고려한 장담금법에 따른 저염 된장의 품질특성 변화를 조사하기 위하여 염 농도를 달리하여 6개 월 동안 발효시킨 후 품질특성 변화를 살펴보았다.

수분 함량에서는 염수 침지한 $12 \%$ 메주 된장에서 $55 \%$ 수준으로 가장 낮았으며, 나머지 된장 시료들은 대략 $60 \%$ 수분 함량을 나타냈다. $\mathrm{pH}$ 는 장 담금 초기부터 메주 된장이 메줏가루 된장에 비해 높았으며, 특히 발효기간 내 $8 \%$ 메주 된장의 경우 감소폭이 적었고 이는 산도 변화에서도 담금 직후부터 발효 6개월까지 메주 된장이 메줏가루 된장보다 낮은 경향을 나타내어 상관성을 보여주었다. 환원당 함량 은 1-2개월 내에 최대값을 나타내고 이후 감소하는 경향을 나타냈으나, 발효기간 내 $8 \%$ 메줏가루 된장이 가장 높아, 염도 및 장 담금법 간에 상관성은 낮았다. 아미노태 질소 변화는 담금 직후에는 염 농도가 낮을 수 록 높은 값을 나타냈으며, 메주 된장에서 메줏가루 된장보다 높은 값을 보였다. 암모니아태 질소 함량은 발효초기에는 $12 \%$ 메줏가 루 된장에서 가장 높은 값을 나타냈으며, 메줏가루 된장이 메주 된장보다 높은 값을 보였지만, 이후 급격히 감소하여 시료 간 차이를 보이지 않았다. a-Amylase 효소 활성은 모든 시료가 발효 초기에는 0.91-0.94 Unit/g 수준이었다가 이후 일정하게 감소하여 0.01-0.06 Unit/g 값을 나타내었는데, 특 히 $8 \%$ 메주 된장에서는 완만한 감소를 보였다. Protease 효소 활성은 발효 2 주차에 메주 된장이 메줏가루 된장에 비해 높은 활성을 나타냈으나 이후 감소하여 비슷한 수준을 나타내었다. 총 균수는 발효초기부터 메주 된장에서 메줏 가루 된장보다 높은 값을 나타내었고, 발효 6개월째 메주 된장이 7.8-8.0 $\log \mathrm{CFU} / \mathrm{g}$ 로 메줏가루 된장(7.2-7.5 $\mathrm{log}$ $\mathrm{CFU} / \mathrm{g}$ )보다 통계적으로 유의하게 높은 값을 보였다. 맛 센서를 통한 맛 분석결과, 비록 $12 \%$ 시판 된장에 비해 제조 한 된장이 높은 짠맛과 쓴맛, 낮은 풍미를 나타내었지만, $8 \%$ 메주 된장이 시판 된장과 전반적으로 유사한 맛 패턴을 보였다. 유리 아미노산 함량은 숙성기간 동안 장가르기 여 부에 따라 메줏가루 된장에서 증가폭은 컸으나 메주 된장의 함량이 높았으며, 염도 $8 \%$ 된장에서 $12 \%$ 된장보다 높은
값을 보였다. 결론적으로 염수 침지 여부에 따른 된장의 품질 특성을 비교한 결과, 장담금 과정을 거친 저염 된장이 품질 특성뿐만 아니라 맛 분석결과에서 좋은 평가를 나타내 었고, 아울러 메줏가루를 이용한 간편 저염 장류 제품 개발 을 위한 기초 자료로 활용될 수 있을 것으로 기대된다.

\section{감사의 글}

본 연구는 2017년도 농촌진흥청 농업기초기반 연구개발 사업(PJ010927)의 지원에 의해 이루어진 것입니다.

\section{References}

1. Chae HJ, Lee HJ (1990) An analytical study on Doenjang recorded in the literature. Korean Life Sci Res, 8, 29-69

2. National Institute of Agricultural Science (2015) Manufacturing technology of fermented food and application of agricultural industry, NIAS, ISBN: 978-89-480-3354-093520, 32-33

3. Park KY, Hwang KM, Jung KO, Lee KB (2002) Studies of the standardization of Doenjang (Korean soybean paste) Standardization of manufacturing method of Doenjang by literatures. J Korean Soc Food Sci Nutr, 31, 343-350

4. Kim DY, Kwon DJ (2014) Quality characteristics of Doenjang manufactured with soybean Koji. Korean J Food Preserv, 21, 434-441

5. Park JW, Lee YJ, Yoon S (2007) Total flavonoids and phenolics in fermented soy products and their effects on antioxidant activities determined by different assays. Korean J Food Cult, 22, 353-358

6. Jung KO, Park SY, Park KY (2006) Longer aging time increases the anticancer and antimetastatic properties of Doenjang. Nutrition, 22, 539-545

7. Lee NR, Lee SM, Cho KS, Jeong SY, Hwang DY, Kim DS, Hong CO, Son HJ (2014) Improved production of poly- $\gamma$-glutamic acid by Bacillus subtilis D7 isolated from Doenjang, a Korean traditional fermented food, and its antioxidant activity. Appl Biochem Biotechnol, 173, 918-932

8. Yang BK, Park JB, Ha SO, Kim KY, Kym KH, Park KY, Yun JW, Song CH (2000) Hypolipidemic effect of extracts of soybean paste containing mycelia of mushrooms in hyperlipidemic rats. Korean J Micro Biotech, 28, 228-232 
9. Cha YS, Yang JA, Back HI, Kim SR, Kim MG, Jung SJ, Somg WO, Chae SW (2012) Visceral fat and body weight are reduced in overweight adults by the supplementation of Doenjang, a fermented soybean paste. Nutr Res Pract, 6, 520-526

10. Jang IH, Ahn MJ, Chae HJ (2004) Manufacturing method for traditional Deonjang and screening of high fibrin clotting inhibitory samples. J Appl Biol Chem, 47, 149-153

11. Kwak CS, Park SC, Song KY (2012) Doenjang, a fermented soybean paste, decreased visceral fat accumulation and adipocyte size in rats fed with high fat diet more effectively than nonfermented soybeans. Journal of Medicinal Food, 15, 1-9

12. Kim, JH, Jia Y, Lee JG, Nam BR, Lee JH, Shin KS, Hurh BS, Choi YH, Lee SJ (2014) Hypolipidemic and antiinflammation activities of fermented soybean fibers from Meju in C57BL/6J mice. Phytother Res, 28, 1335-1341

13. Lim SI, Son SM (2010) Fermentation properties of low-salted Doenjang supplemented with licorice, mustard, and chitosan. Korean J Food Sci Technol, 42, 323-328

14. Jung BM (2003) Physicochemical characteristics of freeze dried soybean paste block with sea mustard.

Korean J Soc Food Cook Sci, 19, 318-323

15. Kim EM, Kim YJ, Yu BH, Choi HS, Sin YJ (2012) Quality characteristics of DIY Kochujang with different ratios of rice-nuruk. Korean J Community Living Sci, 147-147

16. AOAC (1990) Official Methods of Analysis. $15^{\text {th }}$ ed, Association of official analytical chemists, Washington DC, USA, p 335

17. Cho KM, Kang JR, Kim GM (2014) Quality characteristics of low salted garlic Doenjang during fermentation. Korean J Food Preserv, 21, 627-635

18. Kim JY, Yi YH (2008) pH, acidity, color, reducing sugar, total sugar, alcohol and organoleptic characteristics of puffed rice powder added wheat flour Takju during fermentation. J Food Eng Prog, 12, 71-77

19. Kim JW, Doo HS, Kwon TH, Kim YS, Shin DH (2011) Quality characteristics of Doenjang and Meju fermented with Aspergillus species and Bacillus subtilis during fermentation. Korean J Food Preserv, 18, 397-406
20. Kim HJ, Lee JJ, Cheigh MJ, Choi SY (1998) Amylase, protease, peroxidase and ascorbic acid oxidase activity of Kimchi ingredients. Korean J Food Sci Technol, 30, 1333-1338

21. Kim JH, Yoo JS, Lee CH, Kim SY, Lee SK (2006) Quality Properties of soybean pastes made from Meju with mold producing protease isolated from traditional Meju. J Korean Soc Appl Biol Chem, 49, 7-14

22. National Agricultural Products Quality Management Service (2012) Traditional food quality certification system. p 88

23. Byun1 MW, Nam1 TG, Chun MS, Lee GH (2014) Physicochemical and sensory characteristics of Doenjang made by traditional methods. J Korean Soc Food Sci Nutr, 43, 1543-1548

24. Chang M, Kim IC, Chang HC (2010) Effect of solar Salt on the quality characteristics of Doenjang. J Korean Soc Food Sci Nutr, 39, 116-124

25. Lee JY, Mok CK (2010) Changes in physicochemical properties of low salt soybean paste (Doenjang) during fermentation. Korean J Food Eng Prog, 14, 153-158

26. Mok CK, Song KT, Lee JY, Park YS, Lim SB (2005) Changes in microorganisms and enzyme activity of low salt soybean paste (Doenjang) during fermentation. Korean J Soc Food Eng, 9, 112-117

27. Lee SY, Park NY, Kim JY, Choi HS (2012) Quality characteristics of rice-Doenjang during fermentation by differently shaped Meju and adding starter. Korean J Food Nutr, 25, 505-512

28. Kim JG (2004) Changes of components affecting organoleptic quality during the ripening of traditional Korean soybean paste-amino nitrogen, amino acids, and color. J Food Hyg Saf, 19, 31-37

29. Brewing Society of Japan (1999) Component of the alcoholic beverages. Shin Nippon Printing Co Ltd, Tokyo, Japan, p 50-79, 409-418

30. Mody I, de Koninck Y, Otis TS, Soltesz I (1994) Bridging the cleft at GABA synapses in the brain. Trends Neurosci, 17, 517-525

31. Tiedje KE, Stevens K, Barnes S, Weaver DF (2010) $\beta$ -alanine as a small molecule neurotransmitter. Neurochem Int, 57, 177-188 